\title{
Design specifications of a human-powered planter
}

\author{
Especificações de projeto de uma semeadora à tração humana
}

\author{
Giusepe Stefanello ${ }^{I}$ Antônio Lilles Tavares Machado ${ }^{I I}$ Ângelo Vieira dos Reis ${ }^{\text {II }}$ \\ Roberto Lilles Tavares Machado ${ }^{\text {II }}$ César Silva de Morais ${ }^{\text {III }}$
}

ABSTRACT

This study aimed to establish the design specifications of a human-powered punch planter for maize and beans through the application of a systematic design methodology. The most important design requirements and their specifications are related to technical performance and production cost.

Key words: machinery design, manual seeder, agricultural machinery.

\section{RESUMO}

O presente trabalho, por meio de metodologia de projeto sistemática, objetivou hierarquizar os requisitos de projeto $e$ estabelecer as especificações de projeto de uma semeadora puncionadora à tração humana para milho e feijão. Os requisitos de projeto mais importantes e respectivas especificações estão relacionados ao desempenho técnico e custo de produção.

Palavras-chave: projeto de máquinas, semeadora manual, máquinas agrícolas.

Manual portable planters exhibit unsatisfactory performance, structural problems, and imprecise seed metering (MOLIN et al., 2001). In order to a traditional push planter to work properly, it is required previous soil mobilization in the sowing line. Equipment that considers the needs of family farms must be developed (TEIXEIRA et al., 2009; ROMEIRO FILHO, 2012). Of the few initiatives that have been introduced (AREND et al., 2005;
TEIXEIRA et al., 2008; ROMEIRO FILHO, 2012; VIANNA et al., 2014), some were mechanical (FRABETTI et al., 2011) and others were manual (MOLIN \& D'AGOSTINI, 1996) punch planters that use human force, require no tillage, and have a systematic design methodology (STEFANELLO et al., 2014). These models include the Phases Model, which employs informational, conceptual, preliminary, and detailed design phases (BACK et al., 2008; ROZENFELD et al., 2006).

The purpose of this study was to determine the design specifications (DSs) for a human-powered punch planter for the direct sowing of maize and beans. This planter will target the needs of family farms that currently employ manual portable seed planters for this purpose. We began with 13 design requirements (DRs) and 13 client requirements (CRs), which were obtained and assessed during earlier design tasks. The DRs were ranked with quality function deployment (QFD) (REIS \& FORCELLINI, 2006) using the WinQFD software. When the DRs and CRs were compared by assigning them values of $0,1,3$, or 5 (no relation, weak relation, medium, and strong). In the upper portion of the QFD (roof), the DRs were correlated (3: strong positive, 1: positive, 0 : none, -1 : negative, and -3 : strong negative) to obtain a second ranking, which is rarely used (FONSECA, 2000). The list of the DSs was divided into upper, medium, and lower thirds in descending order of importance (REIS

\footnotetext{
IPrograma de Pós-graduação em Sistemas de Produção Agrícola Familiar (PPGSPAF), Universidade Federal de Pelotas (UFPEL), 96010-900, Pelotas, RS, Brasil. E-mail: giusepe.stefanello@ufpel.edu.br. "Corresponding author.

IIDepartamento de Engenharia Rural (DER), Universidade Federal de Pelotas (UFPEL), Pelotas, RS, Brasil.

IIICurso de Engenharia Agrícola, Universidade Federal de Pelotas (UFPEL), Pelotas, RS, Brasil. Received 03.11.16 Approved 05.18.16 Returned by the author 08.15.16 CR-2016-0262
} 
\& FORCELLINI, 2006). The DRs were associated with quantitative goals (limit values or intervals), means of evaluation, and potential negative effects.

The most important contradiction (found in the roof of the QFD) was in the production cost (PC), which if reduced could shorten the service life (SL), or the inverse. Ranking, without correlation of the roof, presented in a list of specifications (Table 1), proved to be more coherent as it prioritized the technical aspects of sowing. The same approach was used by REIS \& FORCELLINI (2006) and TEIXEIRA (2008). As with REIS \& FORCELLINI (2006), the longitudinal regularity of distribution (LRD) was the first priority. By contrast, VIANNA et al. (2014) prioritized the ease of manufacturing associated with greater tolerance, the use of materials, and common standardized processes over metering accuracy, deposition accuracy, and seed damage. They also prioritized the CPs in a similar way to TEIXEIRA (2008), who considered sowing accuracy less important. The requirements for intervals between maintenance (IM) events, the cost of maintenance (CM), total mass (TM), adjustment time (AT), and common manufacturing processes (CMPs) were allocated to the middle third of the QFD. TEIXEIRA (2008) assigned the same importance to TM and AT, and REIS \& FORCELLINI (2006) did the same for CM and AT. Conversely, for the latter authors, CMPs had less importance. The requirements with lower priorities were maintenance time (MT), service life (SL), manual assembly (MA), and common standardized materials (CSM). TEIXEIRA (2008) and REIS \& FORCELLINI (2006) took the same approach. LRD, seed deposition depth regularity (SDDR), and seed damage (SD) are associated with recommendations and technical standards (ABNT, 1994). REIS \& FORCELLINI (2006) considered the same for LRD, although COELHO (1996), REIS \& FORCELLINI (2009), and VIANNA et al. (2014) considered a $60 \%$ goal for single spacings acceptable. This was influenced by errors in seed metering, depositing, depth, and coverage (REIS \& FORCELLINI, 2002). Metering errors are influenced by the tangential speed of the orifices, which should be less than $0.3 \mathrm{~m} \mathrm{~s}^{-1}$ (REIS \& FORCELLINI, 2006; VIANNA et al., 2014). CP was limited to $\mathrm{R} \$ 840.00$ (US $\$ 1.00=\mathrm{R} \$ 3.50$ as of August 2015), a retail value of up to $R \$ 1,400.00$, and a maximum production value of R $\$ 1,050.00$. The goal was close to that discussed by TEIXEIRA (2008) for animal- and mechanicalpowered planters (two rows), which are less complex because they employ greater traction. The humanpowered planters dispense the use of animals and tractors and associated costs for acquisition and maintenance, as well as time, physical space for preparation, and maneuvers. Depth-regulator system should have at least five intermediate positions. The SD associated with the tangential speed of the metering system and the shearing effects of the cutoff device and ejectors was limited to $1 \%$. This agrees with REIS \& FORCELLINI (2006) but not with VIANNA et al. (2014), who stipulated a limit of $2 \%$. The metering accuracy may be reduced when using components that have inadequate shapes, rigidities, dimensions, or tolerances.

IM occurs once a week. The AT includes adjustments to depth, seed coverage, and metering (changes to the metering elements). The mass of the seeder was restricted to obtain a draft of less than 150N. TEIXEIRA (2008) limited the mass of the animal- and mechanical-powered seeder to $80 \mathrm{~kg}$ (two rows). CM involves lubricating the seeds, meter, and inspecting mobile parts and replacing components. CM was limited to R\$ 15.50 per working week, which is in line with the R $\$ 0.14 \mathrm{~h}^{-1}$ defined by REIS \& FORCELLINI (2006) for a precision metering system. The achievement of this goal could reduce the IM (which is in agreement with the cited authors) and reduced the SL. The CMPs considered were those available at most small mills, workshops, and small manufacturing companies. These CMPs included welding, folding, cutting, perforating, and machining. In agreement with REIS \& FORCELLINI (2006) and VIANNA et al. (2014), the goal established was at least $80 \%$, which was assessed by counting the processes. This was inconvenient because it limited the use of innovative technologies or solutions.

The goal for MA was at least $80 \%$ of the assemblies without the use of tools, in agreement with REIS \& FORCELLINI (2006). TEIXEIRA (2008) and VIANNA et al. (2014) set a limitation of two tools for this purpose, alerting to the possible use of a greater number due to the infeasibility of adjusting to the design. In this study, a possible undesirable condition is the increase of CP. According to REIS \& FORCELLINI (2006), this increase occurred because tools were not used for assembly. The CSM requirement had a similar goal to that of REIS \& FORCELLINI (2006) and VIANNA et al. (2014), which should be met in terms of mass and number of materials. According to REIS \& FORCELLINI(2006), and also reported in this study, the performance of the seed metering system may be limited, and the seed planter may be less durable. Under the most rigorous conditions of manual operation, the specifications for the SL matched those from REIS \& FORCELLINI (2006) for a seed-metering system for mechanical 
Table 1 - Design specifications for manual planter: requirements in descending order of importance, goals, method of evaluation and undesirable conditions.

\begin{tabular}{|c|c|c|c|c|}
\hline & Requirements & Objective & Method of Evaluation & Undesirable Conditions \\
\hline \multirow{4}{*}{$\begin{array}{l}\text { Upper } \\
\text { Third }\end{array}$} & $\begin{array}{l}\text { 1. Longitudinal } \\
\text { regularity of seed } \\
\text { distribution (LRD) }\end{array}$ & $\begin{array}{l}=75 \% \text { singles } \\
=10 \% \text { misses } \\
=15 \% \text { multiple }\end{array}$ & $\begin{array}{l}\text { Simulation at test bench and in } \\
\text { field }\end{array}$ & Compromises working capacity \\
\hline & $\begin{array}{l}\text { 2. Production cost } \\
\text { (PC) }\end{array}$ & $<\mathrm{R} \$ 1,050.00$ & $\begin{array}{l}\text { Sum of costs of components, } \\
\text { materials, and labor for } \\
\text { manufacturing and assembly }\end{array}$ & $\begin{array}{l}\text { Compromises quality and } \\
\text { performance of planter }\end{array}$ \\
\hline & $\begin{array}{l}\text { 3. Seed deposition } \\
\text { depth regularity } \\
\text { (SDDR) }\end{array}$ & $\begin{array}{l}>0.02 \mathrm{~m} \pm 0.015 \mathrm{~m} \\
<0.08 \mathrm{~m} \pm 0.015 \mathrm{~m}\end{array}$ & Field measurement & Compromises operational capacity \\
\hline & 4. Seed damage (SD) & $<1.0 \%$ & Laboratory evaluation & $\begin{array}{l}\text { Compromises accuracy of the } \\
\text { planter }\end{array}$ \\
\hline \multirow{5}{*}{$\begin{array}{l}\text { Middle } \\
\text { Third }\end{array}$} & $\begin{array}{l}\text { 5. Interval between } \\
\text { maintenance (IM) }\end{array}$ & $=50 \mathrm{~h}$ & $\begin{array}{l}\text { Simulation at test bench and in } \\
\text { field }\end{array}$ & $\begin{array}{l}\text { Hinders manual assembly and } \\
\text { increases production cost }\end{array}$ \\
\hline & 6. Total mass (TM) & $<30 \mathrm{~kg}$ & Weighing & Insufficient sowing depth \\
\hline & $\begin{array}{l}\text { 7. Adjustment time } \\
\text { (AT) }\end{array}$ & $<5$ min & Timing & $\begin{array}{l}\text { Greater manufacturing } \\
\text { shorter intervals } \\
\text { maintenance events }\end{array}$ \\
\hline & $\begin{array}{l}\text { 8. Cost of } \\
\text { maintenance }(\mathrm{CM})\end{array}$ & $<\mathrm{R} \$ 0.35 \mathrm{~h}^{-1}$ & $\begin{array}{l}\text { Evaluate wear at test bench and } \\
\text { in field. Budget components } \\
\text { and supplies }\end{array}$ & $\begin{array}{l}\text { Shorter intervals between } \\
\text { maintenance events; lower service } \\
\text { life }\end{array}$ \\
\hline & $\begin{array}{l}\text { 9. Common } \\
\text { manufacturing } \\
\text { processes }(\mathrm{CMP})\end{array}$ & $>80 \%$ & Counting & $\begin{array}{l}\text { Limits the use of more elaborate } \\
\text { solutions }\end{array}$ \\
\hline \multirow{4}{*}{$\begin{array}{l}\text { Lower } \\
\text { Third }\end{array}$} & $\begin{array}{l}\text { 10. Maintenance time } \\
\text { (MT) }\end{array}$ & $\begin{array}{l}<10 \mathrm{~min} \text { : exchange } \\
\text { parts } \\
<3 \mathrm{~min} \text { : lubrication }\end{array}$ & Timing & $\begin{array}{l}\text { Smaller intervals between } \\
\text { maintenance events }\end{array}$ \\
\hline & $\begin{array}{l}\text { 11. Manual assembly } \\
\text { (MA) }\end{array}$ & $>80 \%$ for regulating & Counting & Increased manufacturing cost \\
\hline & $\begin{array}{l}\text { 12. Common } \\
\text { standardized materials } \\
(\mathrm{CSM})\end{array}$ & $>80 \%$ & Counting and weighing & $\begin{array}{l}\text { Compromises performance and } \\
\text { durability }\end{array}$ \\
\hline & 13. Service life (SL) & $>1,000 \mathrm{~h}$ & $\begin{array}{l}\text { Indirect evaluation of wear in } \\
\text { laboratory and field tests }\end{array}$ & $\begin{array}{l}\text { Use of costly or rare materials; } \\
\text { increased size, mass, components, } \\
\text { and costs }\end{array}$ \\
\hline
\end{tabular}

planters (1,500h). TEIXEIRA (2008) and VIANNA et al. (2014) referred to a SL of five years, which is compatible with the expected length of this study. Undesirable conditions include the use of costly or rare materials, a larger size, and mass components. This agrees with TEIXEIRA (2008), VIANNA et al. (2014), and REIS \& FORCELLINI (2006), who mentioned the use of lower mechanical tolerances as an undesirable solution.

The ranking of the DRs showed the importance of the planter's functionality and its production cost. Many of the most important requirements are related to the technical performance of the planter, which require the machine to provide a quality sowing operation in order to successfully achieve the demands of target clients. The list of DSs will allow for continuity in the planter design, providing constant orientation throughout this process, ensuring that the needs for a small-scale seed planter are met.

\section{ACKNOWLEDGEMENTS}

To the Public Bidding MCTI/CNPq N. 14/2013 - Universal - Conselho Nacional de Desenvolvimento Científico e Tecnológico (CNPq) - Contract 480020/2013-2, 'Desenvolvimento de tecnologias equipamentos agrícolas para a agricultura de base familiar'. To Coordenação de Aperfeiçoamento de Pessoal de Nível Superior (CAPES) for doctoral scholarship to first author. To Fundação de Amparo à Pesquisa do Estado do Rio Grande do Sul (FAPERGS) for PROBIC scholarship to last author. The paper is part of the first author's doctoral thesis.

\section{REFERENCES}

ABNT (ASSOCIAÇÃO BRASILEIRA DE NORMAS TÉCNICAS). Projeto de Norma 04:015:06:004. Semeadora de precisão: ensaio de laboratório. São Paulo, 1994. 22p. 
AREND, L. et al. Development and test of a modular seeder fertilizer for small countryside properties. Engenharia Agrícola, v.25, p.801-808, 2005. Available from: <http://dx.doi.org/10.1590/ S0100-69162005000300027>. Accessed: July, 7, 2015.

BACK, N. et al. Projeto integrado de produtos: planejamento, concepção e modelagem. Barueri: Manole, 2008. 601p.

COELHO, J.L.D. Ensaio e certificação das máquinas para a semeadura. In: MIALHE, L.G. Máquinas agrícolas: ensaios e certificação. Piracicaba: FEALQ, 1996. p.551-570.

FONSECA, A.J.H. Sistematização do processo de obtenção das especificações de projeto de produtos industriais e sua implementação computacional. 2000. 180f. Tese (Doutorado em Engenharia Mecânica) - CTC/EMC, Universidade Federal de Santa Catarina, SC.

FRABETTI, D.R. et al. Development and evaluation performance of a punch planter for direct sowing of corn. Revista Brasileira de Engenharia Agrícola e Ambiental, v.15, n.2, p.199-204, 2011. Available from: <http://www.scielo.br/pdf/rbeaa/v15n2/ v15n02a13.pdf $>$. Accessed: Nov. 07, 2014. doi: 10.1590/S141543662011000200013

MOLIN, J.P.; D'AGOSTINI, V. Development of a rolling punch planter for stony soil conditions. Agricultural Mechanization in Asia, Africa and Latin America, v.27, n.3, p.17-19, 1996.

MOLIN, J.P. et al. Evaluation of manual planters. Revista Brasileira de Engenharia Agrícola e Ambiental, v.5, n.2, p.339343, 2001. Available from: <http://dx.doi.org/10.1590/S141543662001000200027>. Accessed: July, 07, 2015.

REIS, Â.V. dos; FORCELLINI, F.A. Performance and constructive characteristics of a pneumatic meter prototype for rice seeds. Engenharia Agrícola, v.29, n.2, p.257-266, 2009. Available from: <http://dx.doi. org/10.1590/S0100-69162009000200009>. Accessed: Nov. 07, 2014.

REIS, Â.V. dos; FORCELLINI, F.A. The design specifications of a precision meter for small seeds. Engenharia Rural, v.17, n.1, p.47-57, 2006. Available from: <http://wp.ufpel.edu.br/nimeq/ files/2011/04/Engenharia-Rural-v17-n1.pdf $>$. Accessed: Jan. 07, 2015. doi: 10.1590/S0100-69162006000100033.

REIS, Â.V. dos; FORCELLINI, F.A. Functional analysis in the evaluation of four concepts of planters. Ciência Rural, v.32, n.6, p.969-975, 2002. Available from: <http://dx.doi.org/10.1590/ S0103-84782002000600009>. Accessed: Jan. 09, 2015.

ROMEIRO FILHO, E. An user centered approach to the design of animal traction agricultural machinery. Gestão \& Produção, v.19, n.1, p.93-102, 2012. Available from: <http://dx.doi.org/10.1590/ S0104-530X2012000100007>. Accessed: Jan. 07, 2015.

ROZENFELD, $H$. et al. Gestão de desenvolvimento de produtos: uma referência para a melhoria do processo. São Paulo: Saraiva, 2006. 542p.

STEFANELLO, G. et al. Functional structure of a humanpowered seeder. Ciência Rural, v.44, n.9, p.1583-1588, 2014. Available from: <http://www.scielo.br/pdf/cr/v44n9/0103-8478cr-44-09-01583.pdf>. Accessed: Aug. 15, 2015. doi: 10.1590/0103$8478 \mathrm{cr} 20130020$.

TEIXEIRA, S.S. et al. Agro ecological production characterization in the south of the State of Rio Grande do Sul related to farm machinery. Engenharia Agrícola, v.29, n.1, p.162-171, 2009. Available from: <http://dx.doi.org/10.1590/ S0100-69162009000100016>. Accessed: Nov. 07, 2014.

TEIXEIRA, S.S. Projeto conceitual de uma semeadora de milho e feijão voltada para a agricultura familiar de base ecológica. 2008. 113f. Dissertação (Mestrado em Ciências) - Universidade Federal de Pelotas, Pelotas, RS.

VIANNA, L.R. et al. Development of a horizontal plate meter with double seed outlets. Revista Brasileira de Engenharia Agrícola e Ambiental, v.18, n.10, p.1086-1091, 2014. Available from: <http://dx.doi.org/10.1590/1807-1929/agriambi. v18n10p1086-1091>. Accessed: Nov. 07, 2014. 